\title{
Hypotriglyceridemic effect of Morus alba L., Moraceae, leaves in hyperlipidemic rats
}

\author{
Ana Lúcia B. Zeni, "Mauren Dall'Molin \\ Universidade Regional de Blumenau, Departamento de Ciências Naturais, Caixa postal 1507, 89012900 \\ Blumenau-SC, Brazil.
}

\begin{abstract}
RESUMO: "Efeito hipotrigliceridêmico de folhas de Morus alba L., Moraceae, em ratos hiperlipidêmicos". As folhas de amoreira branca Morus alba L., Moraceae, são utilizadas no Brasil na medicina popular para tratar febre, como protetor do fígado, para baixar a pressão e o colesterol. O extrato aquoso de folhas de $M$. alba foi administrado via oral através de gavagem em ratos hiperlipidêmicos com uma dieta enriquecida com colesterol (1\%) com uma dose de 150 $\mathrm{mg} / \mathrm{kg} /$ dia por quatorze dias que reduziu significativamente em $55,01 \%$ o nível de triglicerídios plasmáticos. Desta forma, o tratamento diminuiu o nível de triglicerídios e uma enzima hepática testada, demonstrando que extratos de Morus alba que tem sido popularmente utilizados possuem um grande potencial para se tornar um fitomedicamento.
\end{abstract}

Unitermos: Morus alba, ratos hiperlipidêmicos, triglicerídios.

\begin{abstract}
Mulberry Morus alba L., Moraceae, leaves are used in Brazil medicines against fever, to protect the liver, to lower the blood pressure and cholesterol. The aqueous extract of leaves of $M$. alba given by oral route to hyperlipidemic rats with diet enriched by cholesterol (1\% by weight) with dose of $150 \mathrm{mg} / \mathrm{kg} /$ day for forteen days reduced significantly by $55,01 \%$ the plasma triglycerides level. Therefore, the treatment not only decreased the plasma level of triglycerides but also affected a hepatic enzyme tested supportting the fact that the extracts of Morus alba that have been used by folk medicine have a great potential to be further developed into a phytomedicine.
\end{abstract}

Keywords: Morus alba, hyperlipidemic rats, triglycerides.

\section{INTRODUCTION}

Hyperlipidemia, resulting from lipidic metabolitc changes, is a major cause of cardiovascular disturbances (Chobanian, 1991). Although a high level of serum cholesterol has been identified as a risk factor for atherosclerosis and coronary heart disease (Kanel et al., 1971), the role of a high level of triglycerides has only recently established as an independent risk factor for such diseases (Cambien et al., 1986; Austin, 1989). The medicinal properties of plants have been investigated in the light of recent scientific developments throughout the world, due to their potent pharmacological activities, low toxicity and economic viability (Sharma et al., 1992).

Mulberry, the plant used in this work, was selected on the basis of the ethnomedical information available. Leaves of Morus alba L. were subject to qualitative phytochemical investigation of the phytoconstituents anthocyanins, prenyflavons, flavonoids, stillbenes, 2-arylbenzofurans, carbohydrates, alkaloid and glycoproteins (Yagi et al., 1976; Nomura et al., 1977; Nomura et al., 1980; Hikino et al., 1985; Gerasopoulos \& Stavorulakis, 1997; Fukai \& Nomura, 1998; Kim et al.,
1999; Kaio et al., 2001; Sharma et al., 2001; Jin et al., 2002; Fukai et al., 2003).

The leaves, roots and fruits have a wide range of pharmacological activities and are used in tradicional Chinese medicine as diabetes, expectorant, sedative, analgesic, diuretic, hypotensive, antiepileptic, antiphlogistic and liver protective (Yamatake et al., 1976; Nomura, 1988; Chen et al., 1995; Quer, 1995; Chevalier, 1996). But in literature, there were a few reports regarding the hypolipidemic effect of $M$. alba leaves (Soares et al., 2005) and two with root barks and fruits (Chen et al., 2005; El-Bebshbishy et al., 2006). In this study we investigated the effect of Morus alba leaves water extract on experimental hyperlipidemic rats.

\section{MATERIAL AND METHODS}

\section{Plant material}

The young leaves of Morus alba L., Moraceae, were collected in December 2005 from Balneário Camboriú-SC, Brazil. The plant was identified by Dr. Lúcia Sevegnani, Professor of Botany and authenticated 
by comparing with the voucher specimen number 2564 located at Herbário Dr. Miguel Pedro Klein of Universidade Regional de Blumenau (FURB).

\section{Extraction}

Aqueous extract of mulberry leaves were prepared at $1.5 \mathrm{~g} \%$, as recommended by the traditional healers, boiling the water and after put this one over the fresh and young leaves and cover for $10 \mathrm{~min}$ (extract was prepared daily). The average percentage yield of this extract was found to be $20.23 \% \mathrm{w} / \mathrm{w}$.

\section{Animals}

Wistar rats, weighting 200-300 g, threee months old, were bred in the animal center of Universidade Regional de Blumenau. They were housed in standard environmental conditions, fed with diet $\left(\right.$ Nuvilab $\left.^{\circledR}\right)$ and water ad libitum. For experimental purpose the animals were kept fasting overnight but were allowed free access to water. Animals were handled in accordance with laboratory animal welfare guidelines, experimental protocols and procedures were approved by the Animal Experimentation Ethics Committee/FURB (002/2003).

\section{Experimental design}

The experiment was carried out with four groups (I, II, III and IV) of eight rats each: Grupo I: normal, sacrificed to obtain normal biochemical parameters (before the experiment); Group II: normal control, fed with normal diet; Group III: hyperlipidemic treated with $150 \mathrm{mg} / \mathrm{kg} /$ day of extract and fed with diet enriched in cholesterol (1\% by weight); Grupo IV: hyperlipidemic control, fed with diet enriched in cholesterol ( $1 \%$ by weight). Control rats (Groups II and IV) received orally vehicle (distilled water) only while group III received $150 \mathrm{mg} / \mathrm{kg}$ of extract orally, suspended in distilled water. The animals were fed 35 days with a hyperlipidemic diet (Rosa et al., 1998), after this period they were treated with extract of M. alba by gavage for 14 days. All biochemical parameters were estimated at the beginning (Group I) and after 49 days of experiment (Groups II, III and IV).

\section{Collection and processing of blood for estimation of biochemical parameters}

Blood samples were collected by portal venous under ether anaesthesia in Eppendorff's tubes $(1 \mathrm{~mL})$ containing $50 \mu \mathrm{L}$ of anticoagulant (heparin) and plasma was separated by centrifuging at $6000 \mathrm{rpm}$ for $15 \mathrm{~min}$. Plasma total cholesterol (TC), high density lipoprotein (HDL) and low density lipoprotein (LDL)-cholesterol, triglyceride (TG), glutamate oxaloacetate transaminase (GOT) and glutamate pyruvate transaminase (GPT) levels were evaluated using a commercial kit. Several hepatic enzymes, such as GOT and GPT, were used as biochemical markers for hepatic damage.

\section{Histological analysis}

Animals were sacrificed by ether inhalation and the liver was removed, which was fixed in $10 \%$ formalin, dehydrated and included in paraffin wax for $5 \mu \mathrm{m}$ sections that was stained with hematoxylin and eosin (HE) and observed under light microscope.

\section{Statistical analysis}

The data were subjected to the analysis of variance (one way ANOVA) to determine the significance of changes, Student's $t$-test were made to analyse the significance of difference between the experimental groups. $p$ values of 0.05 were taken as significant.

\section{RESULTS AND DISCUSSION}

The oral supplementation of M. alba $(150 \mathrm{mg} / \mathrm{kg} /$ day) to hyperlipidemic rats resulted in significant declines in plasma TG (55.01\%) but not significantly to TC (10.57\%), LDL $(7.89 \%)$ as compared to the hyperlipidemic control (Table 1). The HDL decreased $15.17 \%$ but not significantly. Different of negative results obtained in another work with water extract of M. alba leaves (Soares et al., 2005). Recent studies suggest that TG itself is independently related to coronary heart disease and most of the antihyperlipidemic drugs do not decrease TG levels (Bainton et al., 1992; ElHazmi \& Warsy, 2001).

Table 1. Effect of administration of feeding the aqueous extract of Morus alba L. leaves on TG, TC, HDL and LDL in normal and hyperlipidemic rats for 14 days $(\mathrm{mg} / \mathrm{dl})$.

\begin{tabular}{lcccc}
\hline Experimental groups & TG & TC & HDL & LDL \\
\hline Normal control (group I) & $50.30 \pm 18.52$ & $78.30 \pm 15.18$ & $44.50 \pm 9.77^{\mathrm{b}}$ & $21.80 \pm 4.36$ \\
Control (group II) & $47.75 \pm 13.04^{\mathrm{a}}$ & $82.37 \pm 20.92$ & $50.12 \pm 12.35$ & $25.37 \pm 8.63$ \\
Hyperlipidemic treated (group III) & $49.75 \pm 13.04^{\mathrm{a}}$ & $87.50 \pm 4.036$ & $54.375 \pm 4.80$ & $23.75 \pm 4.68$ \\
Hyperlipidemic control (group IV) & $77.12 \pm 13.33^{\mathrm{a}}$ & $96.75 \pm 16.98$ & $62.62 \pm 59.03^{\mathrm{b}}$ & $25.62 \pm 4.80$ \\
\hline
\end{tabular}

Data are expressed as mean $\pm \mathrm{SE}, N=8$.

${ }^{\text {a }}$ Statistical significance from normal control and treated as compared to the hyperlipidemic group $(P<0.05)$.

${ }^{\mathrm{b}}$ Statistical significance from normal control as compared to the hyperlipidemic group $(P<0.05)$. 
The body weight increased significantly in all studied Groups, II, III and IV, respectively, $12.63 \%, 20.90 \%$ and $27.38 \%$ (Data not shown). Administration of aqueous Mulberry leaves decreased the plasma GPT $38.86 \%$ but increased $7.02 \%$ GOT levels in treated rats (Table 2) but not significantly. Although, histological analysis of Group IV liver revealed comparing with Group III, leukocyte aggregations near blood vessels and evident vascular congestion, inflammatory focus was observed in all the liver parenchyma, principally in the perivascular region (Data not shown). Liver cells presented altered metabolic activity, which was also verified by blood GPT analysis, taking these data together is possible suggest hepatocyte death (group IV), according Friedman \& Young, 1997; Burtis, \& Ashwood, 2001 and reduction of severety damage of liver (group III) provocked by hyperlipidemic diet.

Table 2. Effect of administration of feeding the aqueous extract of Morus alba L. leaves on TGO and TGP in normal and hyperlipidemic rats for 14 days $(\mathrm{mg} / \mathrm{dl})$.

\begin{tabular}{lcc}
\hline \multicolumn{1}{c}{ Experimental groups } & TGO & TGP \\
\hline Normal control (group I) & $103.00 \pm 18.67$ & $65.10 \pm 13.48$ \\
Control (group II) & $107.25 \pm 20.19$ & $52.62 \pm 8.97$ \\
$\begin{array}{l}\text { Hyperlipidemic treated } \\
\text { (group III) }\end{array}$ & $126.25 \pm 35.21$ & $65.62 \pm 31.01$ \\
$\begin{array}{l}\text { Hyperlipidemic control } \\
\text { (group IV) }\end{array}$ & $117.38 \pm 34.30$ & $91.12 \pm 60.56$ \\
\hline
\end{tabular}

Data are expressed as mean $\pm \mathrm{SE}, N=8$.

Mulberry leaves were able to prevent hypertrigliceridemia, this indicate a specific inhibitory effect of M. alba on fatty acids synthesis. Such effect has been demonstrated in experiments using M. alba root bark or fruit (Chen et al., 2005; El-Bebshbishy et al., 2006) and in other plants (Chan et al., 1999; Wang et al., 2000; Yeh et al., 2003).

In conclusion $M$. alba leaves aqueous extract of leaves was able to decrease plasma tryglicerides and repress progression of liver damage in hyperlipidemic rats and appears to confirm the hypolipidemic and liver protective effects.

\section{ACKNOWLEDGEMENTS}

The authors are grateful to Dr. Elzira M. Almeida for the collaboration. This research was supported by the Universidade Regional de Blumenau.

\section{REFERENCES}

Austin MA 1989. Plasma triglyceride as a risk factor for coronary heart disease. Am J Epidemiol 129: 249-259.

Bainton D, Miller NE, Botton CH, Yarnell JWG, Suretman
PM,Baker IA, Lewis B, Elwood PC 1992. Plasma triglycerides and high density lipoprotein cholesterol predictors of ischemic heart diseases in British man. $\mathrm{Br}$ Heart J 68: 60-66.

Burtis CA, Ashwood ER 2001. Tietz Textbook of Clinical Chemistry. Philadelphia: WB Saunders.

Cambien F, Jacquenson A, Richard JL, Warnet JM, Ducimetiere P, Claude JR 1986. Is the level of serum triglyceride a significant predictor of coronary death in "normocholesterolemic" subjects? The paris prospective study. Am J E pidemiol 124: 624-632.

Chan PT, Fong WP, Cheung YL, Huang Y, Ho WK, Chen ZY 1999. Jasmine green tea epicatechins are hypolipidemic in hamsters (Mesocricetus auratus) fed a high fat diet. $J$ Nutr 129: 1094-1101.

Chen F, Nakashima N, Kimura M. 1995. Hypoglycemic activity and mechanism of extracts from mulberry leaves and cortex mori radices in streptozotocin induced diabetic mice. Yakugaku Zasshi 115: 476-482.

Chen, CC, Liu LK, Hsu JD, Huang HP, Yang MY, Wang CJ 2005. Mulberry extract inhibits the development of atherosclerosis in cholesterol-fed rabbits. Food Chem 91: 601-607.

Chevalier A 1996. The encyclopedia of medicinal plants. New York: DK Publishingp. 235.

Chobanian AV 1991. Single risk factor intervention may be inadequate to inhibit atherosclerosis progression when hypertension and hypercholesterolemic coexist. Hypertension 18: 130-131.

El-Bebshbishy HA, Singab ANB, Sinkkonen J, Pihlaja K 2006. Hypolipidemic and antioxidant effects of Morus alba L. (Egyptian mulberry) root bark fractions supplementation in cholesterol-fed rats. Life Sci 78: 2724-2733.

El-Hazmi MA, Warsy AS 2001. Evaluation of serum cholesterol and triglycerides levels in 1-6 year-old Saudi children. $J$ Trop Pediatr 47: 181-185.

Friedman RB, Young DS 1997. Effects of Disease on Clinical Laboratory Tests. Washington: AACC Press.

Fukai T, Nomura T. 1998. Proof against 2'-hydroxy-3prenylflavone-oxygen complex by laser desorption/ ionization time-of-flight mass spectrometry. Rapid Commun Mass Sp 12: 1945-1951.

Fukai T, Satoh K, Nomura T, Sakagami H. 2003. Antinephritis and radical scavenging activities of prenylflavonoids. Fitoterapia 74: 720-724.

Gerasopoulos D, Stavorulakis G. 1997. Quality characteristics of four mulberry (Morus sp) cultivars in the area of China, Greece. J Sci Food Agric 73: 261-264.

Hikino H, Mizuno T, Oshima Y, Konno C 1985. Validity of the oriental medicines. 80. Antidiabetes drugs. 4. Isolation and hypoglycemic activity of moran A, a glycoprotein of Morus alba root bark. Planta Med 51: 159-160.

Jin WY,Na MK, Na RB,Lee HY, Bae KH, Kang SS 2002. Antioxidant compounds from twig of Morus alba. Nat Prod Sci 8: 129-132.

Kaio D, Takashi K, Mitsuko M, Yumiko K, Yasuo F 2001. Studies on the constituints of the leaves of Morus alba L. Chem Pharm Bull Tokyo 49: 151-153.

Kannel WB, Castelli WP, Gordon T, McNamara PM 1971. Serum cholesterol, lipoproteins, and the risk of coronary heart disease. Ann Inter Med 74: 1-12.

Kim ES, Park SJ, Lee EJ, Kim BK, Huh H, Lee BJ 1999. Purification and characterization of Moran $20 \mathrm{~K}$ from 
Morus alba. Arch Pharmacol Res 22: 9-12.

Nomura T, Fukai T, Katayanagi M 1977. Oxidative ciclization of morusin with manganese dioxide. Heterocycles 6: 18471854.

Nomura T, Fukai T, Matsumoto, J. J 1980. Studies on the constituents of the cultivated mulberry tree. 6. Oxidative cyclization of morusin. Heteroc Chem 17:641-646.

Nomura T. Phenolic compounds of the mulberry tree and related plants. In: Herz W, Grisebach H, Kirby GW, Tamm $\mathrm{CH}$ 1988. Progress in the chemistry of organic natural products. vol. 53. Vienna:Springer, 87-201.

Quer PF 1995. Plantas medicinales. Barcelona: Labor.

Rosa COB, Costa NMB, Nunes RM, Leal PFG 1998. Efeito dos feijões (Phaseolus vulgaris L.) preto, carioquinha e vermelho na redução do colesterol sangüíneo de ratos hipercolesterolêmicos. Arch Latinoam Nutr 48: 306-310.

Sharma HM, Hanna A, Kauffman EM, Newman HA 1992. Inhibition of human low density lipoprotein oxidation in vitro by Maharishi Ayurveda herbal mixtures. Pharmacol Biochem Behav 43: 1175-1182.

Sharma R, Sharma A, Shono T, Takasugi M, Shirata A, Fujimura T, Machii H 2001. Mulberry moracins: scavengers of UV stress-generated free radicals. Biosci Biotechnol Biochem 65: 1402-1405.

Soares D, Marthendal G, Zimmerman MC, Zeni ALB 2005. Estudo dos níveis lipídicos em ratos após tratamento com infusão de algumas plantas medicinais de uso popular. Rev Bras Farm 86: 71-74.

Wang IK, Lin-Shiau SY, Chen PC, Lin JK 2000. Hypotrigliceridemic effect of Anka (a fermented rice product of Monascus sp) in rats. J Agric Food Chem 48: 3183-3189.

Yagi M, Kouno T, Aoyagi Y, Murai H 1976. The structure of maranoline, a piperidine alkaloid from Morus species. Nippon Nogei Kagaku Kaishi 50: 571-572.

Yamatake Y, Shibata M, Nagai M 1976. Pharmacological studies on root bark of mulberry tree (Morus alba L.). Jpn J Pharmacol 26: 461-469.

Yeh CW, Chen WJ, Chiang CT, Lin-Shiau SY, Lin JK 2003. Supression of fatty acid synthase in MCF-7 breast cancer cells by tea and tea polyphenols: A possible mechanism for their hypolipidemic effects. Pharmacogen J 3: 267726. 